\title{
Foucault and the origins of the disciplined subject: Post-subjectivity as a condition for transformation in education
}

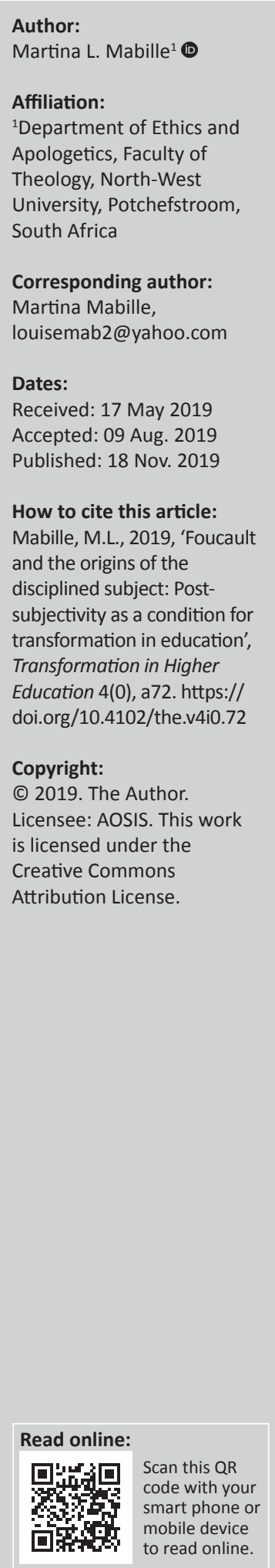

Background: The need for transforming South African education can ultimately be traced to a form of Western subjectivity which dominated Europe since the classical age (1600-1750). The notions of 'discipline' and 'subjectivity' suggest distinct associations with repressive regimes like apartheid, and the present article will argue that the assumptions behind apartheid education cannot be understood without understanding the still more foundational assumptions - taken as axiom - underlying Western subjectivity. This conception of subjectivity underlies the 'disciplined society' and its concomitant ethos of expansion, ranging from its colonial projects to the rise of the human sciences. As a result, it is of considerable value for the South African educational environment to consider Michel Foucault's unmasking of the interplay between subjectivity, truth and power, and to explore the possibilities offered by Foucault's own ethic of transgression.

Aim: Drawing on Michel Foucault's genealogy of the modern subject and archaeologies of modern knowledge, it will be demonstrated that the process of transformation of higher education in South Africa not only provides the opportunity to tend to a grave historical injustice, but also to develop a critique of modernist educational practices of the West and thus to cultivate its own educational ethos as a more just and authentic South African alternative.

Setting: South African Higher Education in the 21st century.

Methods: Foucauldian-Nietzschean genealogy, in the spirit of Foucault's own use of Nietzsche: 'The only valid tribute to thought such as Nietzsche's is precisely to use it, to deform it, to make it groan and protest'.

Result: A re-considered and reconfigured notion of educational identity beyond the confines of modernist Western subjectivity.

Conclusion: While full justice can never be done to the full horrors of the past, the process of transformation in education may provide an opportunity to not only address injustices in the past, but also to create a new African educational ethic which may contribute something truly new to the world's educational heritage.

Keywords: education; enlightenment; Foucault; transformation; progress; power.

From the idea that the self is not given to us, I think that there is only one practical consequence: we have to create ourselves as a work of art.

- Michel Foucault

It is rather surprising that in neither his archaeologies of knowledge nor his genealogies of identity did Foucault ever devote a full investigation to the field of education as he did with health, madness, crime, sexuality or subjectivity itself. This is even more so given the fact that Foucault was personally involved in the évéments [events] of May 1968 and formulated his most important ideas within the context of employment in higher educational institutions. It is still more the case if one considers that education lies on the nexus between archaeology and genealogy, that is, it is the field of transmission of knowledge about the human being and at the same time, the space in which the identity of $\mathrm{Man}^{1}$ as a transcendental guarantor for the validity of this knowledge is forged. Education may thus be viewed as one of the key sites of the 'normalising' tendencies characteristic of modernity and a particularly significant space for the operation of bio-power, a prime example of which may be seen in the institution of apartheid. However, drawing on the later Foucault, it will be demonstrated that such power is not absolute and that ways of resistance 1.The question of Man is central to modern Western epistemologies. Currently problematic, it is addressed below. 
exist. What makes this particularly significant for South Africa is that the process of transformation in South Africa offers a unique opportunity for harnessing such strategies of resistance and cultivating a new ethic of freedom beyond the constraints of Western subjectivity.

The most sustained discussion of education occurs during an interview with Jon Simon at the University of Buffalo (Foucault 1971), Part III of Discipline and Punish, and a general discussion with high school pupils for the journal Actuel in 1977. Towards the 1970s, Foucault shifted from his archaeological concerns with the construction of knowledge to the more Nietzschean question of the shaping of the subject with his substantive research into punishment and sexuality.

It is no accident that Foucault's most important discussion of education occurs within this context, rather than his earlier archaeological work on the classification of knowledge since the classical period (although the term 'discipline' immediately suggests both a branch of knowledge and the practice of training people to obey a set of rules or code of conduct under threat of punishment). He sees the advancement of modern educational institutions as closely intertwined with the emergence of a disciplined, interiorised subject.

This subject is by no means innocent: Morgan Brigg, for example, draws a parallel between Foucault's shift from sovereign power to bio-power and the shift among colonial powers from colonial to 'developmental' discourse (Briggs 2002). As latter-day educational ideals remain grounded in the ideals set during the classical age, it may benefit latterday educational practitioners to consider the complicity of these ideals in forging a subject designed by, and for relations of bio-power. The larger Western position is mirrored in the South Africa of the apartheid era, about which Fourie and Strydom write that the institutional phase of higher education studies in South Africa tended, until the late 1970s, to operate largely within a historical and educational mould and took the form of the histories of individual institutions' (1999:155).

\section{Foucault himself admits:}

Among all the societies in history, ours - I mean, those that came into being at the end of antiquity on the Western side of the European continent-have perhaps been the most aggressive and the most conquering; they have been capable of the most stupefying violence, against themselves as well as against others.... ... It must be kept in mind that they alone evolved a strange technology of power treating the vast majority of men as a flock with a few as shepherds. They thus established between them a series of complex, continuous, and paradoxical relationships. (Foucault 1988:11)

In his revisionist account of the changes that occurred in 18th and 19th century penal reform, Foucault challenges the classic liberal (also Marxist and Weberian) accounts that the abolition of torture and public spectacle in favour of gentler methods of correction simply represents hardwon humanitarian progress, and that 'society' was advancing towards a more humane state. Instead, he draws attention to the significance of the displacements which occurred with respect to the object of punitive practices. For Foucault, much of modernity obscures the need for explanation: among the reasons for the success of the operation of modern power networks is that it seems to present its manifestation as self-evident: What else can we do but to incarcerate prisoners on a massive scale? What is there to do with the insane except to send them to asylums? Moreover, surely, modern-day schooling has been nothing but a tool of emancipation from a state of ignorance? Taking his cue from Marx, Foucault traces the proliferation of techniques of subjection in the West to the increasing demands of capitalism. As wealth became accumulated in larger quantities in ports, warehouses, workshops and factories, more efficient forms of control were required to prevent theft and keep track of the flow of money. In addition, greater urban populations had to be controlled and an increasingly complex legal system ${ }^{2}$ demanded a greater literate population. More importantly, the new goals of increased growth and productivity meant that workers had to be rendered docile ('discipline') to maximise their working potential and integrate them into mechanised processes of production. The emergence of the ideal of a fully literate populace from the late 18th century is far from simply an instance of Enlightenment emancipation, but a decisive moment in the history of subjection: the exchange of sovereign power for bio-power.

'Bio-power' indicates the sum of disciplines, techniques, institutions and discourses which developed in order to trace track, survey, constitute and shape populations as well as individuals. In contrast to the old sovereign power, with its seat in the body of the monarch and cumbersome need for violent spectacle (think about the execution of Damiens with which Foucault famously opened Discipline and Punish) for the broad population, the new techniques of visibility were of the population subject to control. The growing need to maximise utility led to the development of what Foucault called 'the art of light and the visible' (Foucault 1979:7). The classical age saw an increased emphasis on visibility, with hospitals, workshops, factories, asylums, shops, housing projects - and, importantly, schools - organised to ensure the greatest degree of visibility possible with a single gaze: Openings, walls, aisles, gaps and temporary divisions were designed to maximise survey ability. From the 18th century onwards, school pupils were organised, hierarchised and divided to ease inspection. It is not difficult to draw a parallel with the desire of the South African regime from 1948 to categorise and classify along racial lines. In the case of South Africa, as Engelbrecht notes, separated education departments, situated under the tripartite governmental system, led to a society fragmented and categorised under racial lines (2006:254). Foucault writes that the scope of this gaze became increasingly wider: 'For a long time, ordinary individuality - the everyday individuality of everybody -

2.See, for example, the famous Jarndyce v Jarndyce in Charles Dickens' Bleak House, discussed by Donna Leon in Willful Behavior (2010) London: Penguin, p. 308. 
remained below the threshold of description. The disciplinary methods lowered the threshold of describable individuality and made of this description a means of control and a method of domination' (Foucault 1979:7). In schools, increasing attention was paid to punctuality, gestures, poses, attitudes as well as differences in behaviour that previously went unnoticed or were not considered to be of any significance.

In modernity, power became directed towards generating a self that relates to itself through a codified, colonised and above all continuous form of critical self-reflection which imposes hegemony as it observes and demands certain desirable characteristics by delegitimising all other alternatives as 'other'. By defining the self as a figure of hidden circuitous causalities and deep-harbouring truths, panoptic power succeeds in developing Western Man - and all the others upon which he exercises his colonial power - as deep-examining selves. A particularly significant mechanism that aided this process was the examination, which became widespread in schools as well as hospitals and asylums. Rooted in the increasingly powerful natural sciences and subject to inductive logic, the examination allowed for a level of objectification with minute specificity and allowed for the tracking, recoding and grading of differences between individuals, refining the process of individualisation. The individual was transformed into a 'case,' who may be described, judged, analysed, measured, compared with 'other' and who has to be 'trained' or corrected, classified, normalised or excluded. This is the operation of the Nietzschean 'will to truth' at its most meticulous: micropenalties were introduced at different points in order to force behaviour into compliance with the normalising judgements implied by the exam's telos[end]. It is also a form of evaluation which steers individuals towards utilitarian aims: while the aim of the examination cannot be reduced to a purely Benthamite pain or pleasure calculus, the academic examination is designed to favour distinct outcomes. This left little playroom for the developing pupil.

It is particularly significant to note that access to higher education has always been a prominent item on the agenda for the apartheid government. Concomitant with that government's economic privileging of white communities was the direction of resources towards rendering white pupils 'visible' in order that they can be 'cultivated'. In other words, it is possible to say that one of the dividing lines between those privileged by apartheid education and those allowed to slip under the surface of invisibility was the normalising gaze. The purpose of the normalising gaze was to establish certain forms of behaviour, attitudes and abilities while at the same time excluding others. However, in contrast to other critics of modernity (i.e. Weber and the Frankfurt School), Foucault's normalising gaze does not simply demand similitude. While it limits the range of possibilities of behaviour (confining those who fail to meet the standards of normalisation to categories such as the perverse, delinquent or insane), within the limits of the 'normal' itself, the normalising gaze also categorises, identifies, classifies and orders, thus helping to constitute difference. To a significant extent, the 'normal' is always deferred - it is always refined, redefined and being worked upon. Foucault writes in this respect: 'In a sense the power of normalization imposes heterogeneity, but it individualizes by making it possible to measure gaps, to determine levels, to fix specialties and to render these differences useful by fitting them one unto another' (Foucault 1979:84). In the case of South Africa in particular, it is clear that education served as a crucible for the development of white normality, with an 'unshaped', 'uncultivated' other slipping beneath the surface of visibility. Paradoxically, higher visibility also renders resistance to the norm more problematic. In the case of South Africa in particular, it has to be noted that one of the tools engendering the division between visibility and invisibility is funding. Money steers the 'gaze'. Wangenge-Ouma writes in this respect that 'Funding is probably the most important tool that was utilised by the apartheid state, and is being utilised by the post-apartheid state, to achieve the desired access policy goals. The use of funding mechanisms to achieve particular access goals is not surprising. It is generally agreed that the funding of higher education is intricately linked with issues of accessibility' (2012:831).

What renders resistance to such power mechanisms even more difficult is that at the same time that people are commodified as exchangeable objects in a highly disciplined and abstracted labouring force, 'the individual is carefully fabricated' (Foucault 1979:217). Within carefully delimited hierarchies, disciplinary power finds and maintains hierarchies and 'separations' between those on differing ranks, and even those on the same rank. This means that legitimate channels of resistance are also codified and predetermined. Not only are the 'useful' and useless' separated, but also a 'continuous individualising pyramid' (Foucault 1979:220) is established (what Marx called the 'reserve' of labour, but also to ensue continuous control). At the heart of modernity lies a mechanism 'which coerces by means of observation' (Foucault 1979:220). Observation, illumination and various forms of 'unlocking' and 'bringing to the surface' became the mode of relating to the self and the natural world. Atoms of natural bodies (human or otherwise) became objects of knowledge to be examined, classified, ordered around or excluded. As it is no accident that modern education was forged in the crucible of the interplay between power and use, it is no accident either that the quintessential tools of early modernity were the telescope (Galileo), the observatory, the lens and a variety of light beams. As such tools were essential in the development of an ordered and classified natural world (to a greater degree at least from the 'given' Aristotelian chain of being), 'the observatories of humanity rendered it possible to constitute pacified and controlled subjects' (Foucault 1979:171). It should be noted that this form of visibility is not only distinct from, but also for all intents and purposes, opposed to the sense of visibility for which Fanon (1986) argues in Black Skins, White Masks. Fanon draws upon a classic Hegelian notion of recognition, 
according to which an oppressed group gains the opportunity to join the charmed circle of 'the recognised' - those who are raised from a state of nature towards a state of full humanity. For Foucault, as for Freud, this process itself is fraught with danger and new forms of power.

If tools amplifying natural vision exemplified modern humanity's control over nature, then the technology that exemplified the power behind his own self-constitution has to be Bentham's Panopticon. This famed architectural scheme was composed of a ring of fully illuminated cells built around a central watchtower. The building was designed to allow the guard to be able to see the prisoners without them, in turn, being able to see the guard. 'All that is then needed is to put an overseer in the tower and place in each of the cells a lunatic, a patient, a convict, a worker or a schoolboy'. What is often overlooked is that besides the debate whether the panopticon really served as the basis for penal institutions, it was a school, the 'pedagogical machine' of the École Militaire, which provided the original inspiration for Bentham's Panopticon (see, e.g. Foucault 1986:173).

Aside from the obvious labour-and money-saving advantages, this installed in prisoners a sense of being observed without them being able to empirically verify this fact, instituting a radical asymmetrical relationship. With the ever-present possibility of being observed, the individual - for this is what he has fully become by now - is compelled to watch over himself, to become for all intents and purposes his own guard. ${ }^{3}$ According to Foucault, the Panopticon displays 'which each individual under its weight will end by interiorizing to the point that he is his own overseer, thus exercising this surveillance over and against himself' (Foucault 1980a:155). Unlike the blunt power of the communist or fascist state, the aim is not simply to entrap subjects that would otherwise resist, but to create subjects that would produce their own gazes, interiorised disciplinary gazes with a thoroughness and depth that could never be sustained from without. This 'supremacy of light' demands that its subjects become sources and relays of light themselves, to such an extent that the function of this relentless will to observation becomes itself autonomous. In other words, if the panopticon aims at pure light, or pure transparency, then what one might call the autopticon, or the deep self, aims at an object that constantly moves beyond reach, at best a 'dark shimmer' (Foucault 1980a:151). With the rise of panoptic disciplinary power, it is no longer simply the deviation, visible error or crime that is judged, but also the drives, instincts, passions and desire that lurk beneath the visible: 'these shadows lurking behind the case itself' (Foucault 1979:17, my emphasis). The judgement of the disciplinary gaze is generally characterised by a depth dimension: it deciphers, compares, measures and analyses all with a view (!) to render visible. The most obvious examples are prisons and mental institutions, but it is also discernible in the relentless tracking of children at schools through constant evaluation and examination.

3.An interesting pedagogic parallel would be intercom systems in schools that allow principal to listen into classrooms without being able to be observed or listened in himself or herself.
Concomitant with this development in the late 19th century was the proliferation of anxieties about children: their sexualities, moral character and performance. It, in fact, amounted to nothing short of the re-arrangement of the adult-child relationship, the multiplication of activities and sites designated especially 'for children' (i.e. 'children's literature' and the project of sentimentalising children during the Victorian era) and the invention of education as a science.

Rather surprisingly, Foucault locates the inner receptacle for the operation of the disciplinary gaze in the soul. Far from being a leftover from a more religious age, the soul acts as general referent to disciplinary power: it represents the core of that which is educated, trained, punished, normalised and identified.

Similar to the shift from surface phenomena to the depths of the inner sinful self which accompanied the transition from pagan Europe to Christianity, from the mid-19th-century, the locus of punishment was no longer the body, but the soul. Penance now operated upon 'the depths on the heart, the thoughts, the will, the inclinations' (Foucault 1979:16). It was 'intended not (just) to punish the offence, but to supervise the individual, to neutralize his dangerous state of mind, to alter his criminal tendencies' (Foucault 1979:18). The punishment carried with it 'an assessment of normality and a technical prescription for a possible normalization' (Foucault 1979:21). What is more, 'humane' penal procedures became entangled with a new corpus of knowledge, a science of penology, whose purpose was the 'management of the depths of the human soul' (Rose 1990:7). The soul is both the result of power, and that which allows it to operate on micro-level. According to Foucault, as the body of the premodern king was duplicated and became the atemporal embodiment of power in the medieval period, the bodies of those within institutions of disciplinary power engender their own form of duplication. The soul became an 'inner self' - that which surveys and governs from within, the 'real' self, that which must be found and cultivated at all costs. The soul is each individual's very own autopticon, which represents the panopticon under the flesh of the individual's own being. The soul is the 'reality reference' of the power operating in schools, the workplace, asylums and prisons. It is that which is identified, objectified, classified, pacified and educated. Perhaps, most significantly, the soul is that which surveys from within and makes external observation almost superfluous.

A particularly significant manifestation of the operation of power upon the 'deep self' or the soul occurs in the 'moralising' practices characteristic of both late modern asylum and educational practices. With the birth of the asylum and the universalisation of modern schooling, guilt was used to produce more pacified, responsible and unified selves. This is mirrored in juridical practices of enquiry that moved far beyond the individual acts and tried to isolate the tendencies, drives and deepest personal desires that supposedly constituted the 'identity' of the delinquent. Both disciplinary power and the operations of the inner autopticon are pre-occupied with minutiae. 
For the disciplined man no detail is unimportant, but not so much for the meaning that it conceals within it as for the hold it provides for the power that wishes to seize it. (Foucault 1979:40)

It is interesting to note that within the pedagogic context, expanding numbers of school children, re-valuated curricula and increasing numbers of university-trained teachers, the emphasis in school punishments shifted from vengeance to a kind of 'moral orthopaedics' and amendment of personal flaws. Being part of an increasingly hyper-capitalist global order means that South African needs for transformation in education are often superseded by managerial needs. As Kistner points out, South African transformation is not only threatened by 'old-fashioned transformation-resistant white fuddy-duddies', but also internalised models of 'social value' in the human sciences and 'streamlining', 'fast-tracking', costcutting and 'managerialism in the higher education system'. ${ }^{4}$

It may still be difficult for a post-Rousseauian society to stomach, but depth is not a natural dimension of existence. Unlike the pre-Socratic Greeks, for whom the surface was the main field of operation, the modern subject experiences the visible as a barrier between himself and the true meaning that he seeks. Foucault argues that it should be seen as a correlate of the effect of a variety of technologies operating upon the individual. Even the notion of the 'individual' is far from innocent in this respect. Along with the creation of the 'soul, the dimension of depth is created by designated sex as "the secret" that is surreptitiously identified by the actions, thoughts, emotions and desires' of the self. A kind of 'universal signified', which must be uncovered at all costs, signifies true self beneath the contingencies of appearance. Sex operates as much more than procreation of pleasure, but constituted the true meaning beneath the visible, the truth that is always 'elsewhere'. Immediacy is always deferred. The visible is a barrier between ourselves and the truths that we seek. As sex is discursively attached to the visible, the visible is always expanding, presenting a range of objects between ourselves and the truths we ultimately seek.

We are deep selves not only because we are taken to be beings with a particular dimension of depth, but we are also become beings directed towards depth. One may call it a being-unto-depth. Because the promise of freedom is promised within the depths of self, one is obliged to delve deeply and 'tell what one is and what one does what one recollects and what one has forgotten, what one is thinking and what one thinks one is not thinking' (Foucault 1980a:60). The failure to do this would perpetuate and expand our sense of authenticity, our 'repression', and render us blind to our actual nature. As Lionel Trilling (1972:307) notes, the mere word 'authentic' bears traces of violence: 'Authentheo; to have power over, also to commit a murder. Authentes: not only a master, but also a perpetrator, a murderer, even a self-murderer, a suicide' (Trilling 1971:131).

However, as Foucault demonstrates, this promise of freedom is merely a ruse and that draws people into a field of operation for a variety of power strategies. It is, in fact, a colonised space 4.Paper unpublished, see reference list. where selves are trapped to become the object of power. Unlike the medieval period, truth is no longer 'the child of protracted solitude' (Foucault 1980b:131) discovered privately and in silence. Instead, it became a common phenomenon 'a thing of this world it is produced only by multiple forms of constraint' (Foucault 1980b:131). In a marked difference to Hannah Arendt, Foucault does not find empowerment in the shared public character of truth, but a complex site of repression. This means that there is no 'final' point of power, which is by no means teleological in character. Power proliferates and fragment is the 'discovery' of the self, and the dimensions it 'discovers' never depletes itself.

It is particularly clear where sexuality is concerned, which Foucault illustrates at the hand of the concept latency. Sex as it appears is always suspect: sex 'truly' resides' in the depths of the self which are beyond easy access. We are obliged to search for it, but we can neither search deep enough, nor do it alone. Discovering sex is always to occur with the aid of 'the other who knows' (Foucault 1980a:70). As beings defined by our profound depths, we require experts to help us find ourselves and identify who we really are. Such experts include psychiatrists, psychologists, teachers, therapists, counsellors and other figures of authority - the masters of truth. Through the demands of such authorities, an endless number of discourses develop around the task of deciphering, analysing, codifying and locating the truths extracted from the deep. This allows such authority figures to classify the subjects revealed through these truths on scales of normalcy.

While sex is concerned, the truth is above all defined in terms of unity. The task of recovering our 'true' sexuality has in late modernity become the meta-narrative of our liberation. However, as Foucault demonstrates, in trying to 'liberate' our sexuality, we do not place ourselves beyond power. Instead, we are active in its deployment: [we] 'are fastened to the deployment of sexuality that has lifted up from deep within us a sort of mirage in which we think ourselves reflected - the dark shimmer of sex' (Foucault 1980a:157). We may say that we entered into a Faustian bargain when we, in exchange for sexual liberation, gave up our Miranda Escobedo - the right to remain silent. This does not mean that one is only allowed to talk about sex, but that all aspects of life become governed by the rules and demands governing sex. On the one hand, we find the positing of a definite unity. On the other hand, we are told that this essential unity is so elusive that it requires constant surveillance by others to discover it. Foucault notes that during the 19th century, the family became increasingly defined through its sexual features. Boys and girls are separated (also in schools, and such schools became increasingly 'prestigious'), great attention is paid to infant sexuality, masturbation and 'family health' became an object of state interest, with schools often being units of access. Sexual forms of deviation are identified, codified and multiplied. This is mirrored in the multiplication of the 'surfaces of intervention' increasingly accessible to schools, psychologists and their forms of the juridicoepistemological power formation. 
The discussion of the formation of the juridical model of subjectivity would be incomplete without referring to its archaeological compliment. In The Order of Things (1973), Foucault engages in a theoretical analysis of the modern 'sciences' of 'man'. In this text, he is interested in exposing (sic) the historical a priori of modern theories of the human subject:

This a priori is what in a given period, delimits in the totality of experience a field of knowledge, defines the mode of being of the objects that appear in that field provides man's everyday perception with theoretical powers and the defines conditions in which he can sustain a discourse about things that is recognized to be true. (Foucault 1973:158)

As an epistemic nexus that is at once subject and object, Foucault claims that the concept 'man' does not represent the essence of homo sapiens [the human being] in any ahistorical sense, but represents a being that burst upon the intellectual scene at the beginning of the 19th century and acted as a transcendental condition for the existence of the human sciences. Foucault maintains that a new epistemic space with new demands and possibilities began to emerge with the receding of the classical age. During this period, truth was understood in terms of an object's position with respect to the table of representation which was constructed to represent God's order of the universe. As a result, representation was the mode of expression of truth about the word. However, representation soon made way for a model natural history based on organic structure, 'an internal principle not reducible to the reciprocal interactions of representations' (Foucault 1973:64). Foucault demonstrates that as the internal principle of inflection began to replace the classical logic of representation - reflected in among others, Ricardo's model of labour, Cuvier's primacy of functions and Ropp's grammatical wholes, objective truth, like the truths of the subject, began to recede within the hidden depths of the world.

In the space left behind by 'truth',

man soon emerged. This being stands at the centre of life, language and nature, and he - and he is pretty much a he - finds that he is only accessible through these fields of knowledge and that they determine his identity. He finds himself in the paradoxical position of being at once a transcendental guarantor for, and at the same time a result of an irreducible anteriority. (Foucault 1973:303)

As great as is the gap between the finite subject and the discourses which constitute his identity, everything given in thought is in itself based upon finitude. As man stepped unto the throne vacated by God, he found that the world once guaranteed by God has deserted his humanist inheritor. As man attempts to ground the order of the same, he merely finds that 'his language, his thought, his laughter in the space of that already dead God' (Foucault 1973:385). Despite the plethora of disciplinary practices, man has not succeeded in establishing an ontology final and solid enough to allow Man to be fully present to himself. The subject of modernity who invited himself to be free from the restraints of tradition and sovereign power already finds himself inscribed in a network of power where he not only finds himself already enslaved and enslaving others - but chasing a mirage that will never be fully and satisfactorily present. Subjectivity was not only born in chains, but also in failure.

Thus, as Flynn points out, 'man' is a mere flatus vocis in history, even for the human 'sciences' (2005:31). In other words, there is neither foundational principle, nor originary cause to either a man or his foundational sciences. Words such as 'man', 'author', 'subject', 'civilised' and 'natural' dissolve under Foucault's nominalist scrutiny. We have moved way beyond a past where a Kant could deal in epistemological absolutes. Neither institution nor epistemology can stave off criticism by appealing to holiness and absoluteness. The subject has become unmasked as a foundational prejudice.

If there is a threat of endless measureless following in the wake of an exhausted cogito [self], it also offers endless possibilities not only for resisting the legacy of Western subjectivity or objectivity, but even of overcoming it. Among what Foucault has termed the 'unthought', the shadow that was cast with Descartes's 'I think', the construct that was supposed to lead to truth and certainty came the abyss of the unthought.

However, it may be well that this very abyss offers a way out from the great confinement of subjectivity. It may well be the very domain which offers an opportunity to imagine a self that is shaped by an aestheticised consciousness rather than a discipline one, a form of identity that is open-ended rather than teleological and does not take the demands of late-modern capitalism as its ultimate raison d'être [reason for existence]. For Foucault, there is considerable freedom to be found in the fact that there is no original identity to be hunted down, no need for a philosophical mole to burrow beneath appearance for a stability, which, even if found, is unlikely to be able to serve as stable foundation. There is no need to fear something originary unknown, alienated, concealed or repressed, which leaves the late-modern self free to engage in a hermeneutics of self-interpretation or an ethics of play. In other words, rather than a Barthesian sense of erasure, Foucault envisions a self that is created rather than produced. He therefore celebrates the death of Man as harbouring the potential of new philosophical possibilities beyond the horizon of Western subjectivity and educational ideals formulated beyond discipline, managerial models and use value:

The end of man ... is the return to the beginning of philosophy. It is no longer possible to think in our day other than in the void left by man's disappearance. For this void does not create a deficiency; it does not constitute a lacuna that must be filled. It is nothing more, and nothing less, than the unfolding of a space in which hit is once more possible to think. (Foucault 1973:342)

If the end of Man is harnessed, and its paradoxical nature understood, it should be possible to construct a form of identity beyond the struggle between visibility and nonvisibility. The task of education should be framed in terms of finding and establishing fields of self-creation capable of offering alternatives to the utilitarian ethic that underlies late capitalism. Knowledge is not archived, but communal, rendering it possible to be transferred in a fluid, democratic and stimulating way. 


\section{Acknowledgements}

The author acknowledges the opportunity to be part of the postdoctoral programme of the NWU.

\section{Competing interests}

The author has no conflicting interests in the current situation.

\section{Authors' contributions}

I declare that I am the sole author of this research article.

\section{Ethical consideration}

This article followed all ethical standards for a research without direct contact with human or animal subjects.

\section{Funding}

This research received no specific grant from any funding agency in the public, commercial or not-for-profit sectors.

\section{Data availability statement}

Data sharing is not applicable to this article as no new data were created or analysed in this study.

\section{Disclaimer}

The views and opinions expressed in this article are those of the author and do not necessarily reflect the official policy or position of any affiliated agency of the author.

\section{References}

Briggs, M., 2002, 'Post-development, Foucault and the Colonization Metaphor' Third World Quarterly 23(3), 421-436. https://doi.org/10.1080/01436590220 138367

Ellison, D., 1985, Rousseau and modernity, Cambridge University Press, Cambridge.

Engelbrecht, P., 2006, 'The implementation of inclusive education in South Africa after ten years of democracy', European Journal of Psychology of Education 21(3), 253-264. https://doi.org/10.1007/BF03173414

Fanon, F., 1986, White masks, black skins, Pluto Press, New York.

Flynn, T., 2005, 'Foucault's mapping of history', in G. Gutting (ed.), The Cambridge companion to Michel Foucault, pp. 29-48, Cambridge University Press, Cambridge. https://doi.org/10.1017/CCOL0521840821.002

Foucault, M., 1971, 'J.K. Simon: A conversation with Michel Foucault', Partisan Review 38, 192-201.

Foucault, M., 1973, The order of things: An archaeology of the human sciences, Vintage Books, New York.

Foucault, M., 1979, Discipline and punish, transl. A. Sheridan, Vintage Books, New York.

Foucault, M., 1980a, The history of sexuality, transl. R. Hurley, An introduction, vol. 1, p. 157, Vintage Books, New York.

Foucault, M., 1980b, 'Power/Knowledge', in C. Gordon (ed.), Pantheon Books, New York.

Foucault, M., 1988, 'Truth, power, self: An interview with Michel Foucault', in L.H. Martin, H. Gutman \& P.H Hutton (eds.), Technologies of the self, pp. 9-15, University of Massachusetts Press, Amherst, MA.

Fourie, A.H. \& Strydom, M, 1999, 'Higher education research in South Africa: Achievements, conditions and new challenges', Higher Education 38, 155-167. https://doi.org/10.1023/A:1003756016644

Kistner, U., 2010, A South (African) dream? Negotiating affirmative action for social cohesion in the transformative state: Policy, platitudes, progress and prospects, Pretoria, February 25-26, (unpublished), An abridged version appeared under the title 'Under new management' in the 'Beyond Matric' Supplement of the Mail and Guardian, April 16-22, pp. 5-6.

Rose, N., 1990, 'Governing the enterprising self', Unpublished paper presented at on the values of the enterprise culture, University of Lancaster, September 1989, The revised version is published in P. Heelas \& P. Morris (eds.), The values of the enterprise culture: The moral debate, Unwin, London.

Trilling, L., 1972, Sincerity and authenticity, Harvard University Press, Cambridge, MA.

Wangenge-Ouma, G., 2012, 'Tuition fees and the challenge of making higher education a popular commodity in South Africa', Higher Education 64(6), 831-844. https:// doi.org/10.1007/s10734-012-9531-6 